Copyright (C) 2021 by Cherkas Global University

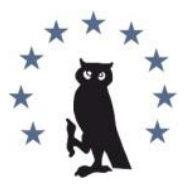

Published in the USA

Media Education (Mediaobrazovanie)

Has been issued since 2005

ISSN 1994-4160

E-ISSN 2729-8132

2021. 17(4): 654-663

DOI: $10.13187 / \mathrm{me} .2021 .4 .654$

https://me.cherkasgu.press

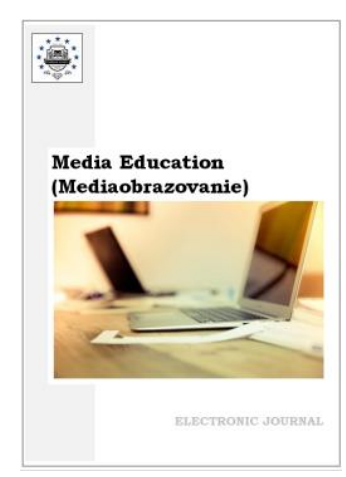

\title{
Students' Media Literacy Concerning the Development of Meta-subject Connections as a Key Sociological Analysis of Attitudes Provided by Future Elementary School Teachers in Relation to Implementation of Film Education in the Classroom Format
}

\author{
Elena Lomteva ${ }^{\mathrm{a},}{ }^{*}$, Natalia Vorobyeva ${ }^{\mathrm{b}}$, Alexei Demidov ${ }^{\mathrm{a}}$ \\ a Russian Academy of National Economy and Public Administration \\ under the President of the Russian Federation \\ b Moscow City Pedagogical University, Russian Federation
}

\begin{abstract}
The article presents results of a survey of teacher college students on their attitude and readiness to implementation of film education in the elementary school educational process. The work was conducted by the Center for Economics of Continuing Education (CECE) of RANEPA and the Institute of Secondary Vocational Education (ISVE) named after K. Ushinsky of the Moscow City Pedagogical University (MCPU) in 2021 and was based on the quantitative method of sociological research. A total of 318 respondents - undergraduate students enrolled in various secondary vocational education (hereinafter referred to as SVE) programs in the field of pedagogics - were interviewed.

The article substantiates that the majority of future elementary school teachers support integration of film education in the elementary school educational structure and analysis of data obtained during the study showed that future teachers' readiness for implementation of this type of activity does not mean availability of exact knowledge of the basics of film education and media pedagogics as well as methodological approaches to teaching of the subject matter.

The materials presented in the article allow readers to form methodological didactic approaches to the problem of students' training at the level of education in SVE organizations as well as consider issues of readiness of future teachers to implement film education in their pedagogical activities.
\end{abstract}

Keywords: education, film education, college, critical thinking, media education, elementary school age, secondary vocational education.

\section{Introduction}

The idea of film education integration into the educational process of schools and a wider range of educational organizations was proposed by the Union of Cinematographers of Russia back in 2012, when the latter presented a draft list of '100 films' which were recommended for viewing during optional classes at schools. However, this initiative was suspended due to facing certain difficulties in transferring ownership of copyright and related rights, absence of 'media education' and 'film education' concepts in the Russian legal and regulatory framework and a number of other factors. At the same time, teachers' attitudes toward the initiative were not unequivocal either: most of them had a fear that it would be changed from a voluntary initiative to a mandatory burden

\footnotetext{
* Corresponding author

E-mail addresses: lomtevaev@inbox.ru (E. Lomteva), Nvorobyova@mgpu.ru (N. Vorobyeva), demidov-aa@ranepa.ru (A. Demidov)
} 
with the great amount of reporting. A significant factor was also represented by virtual absence of media teachers in the Russian educational system. The Public Chamber of the Russian Federation held a roundtable discussion on problems of film education and media pedagogics in the educational process back in 2018.

A number of events held in the field of media education and film pedagogics have been organized and conducted in the last three years by the Center for Continuing Education Economics of RANEPA (hereinafter referred to as CCEE RANEPA) in cooperation with the Association of Film Education and Media Pedagogics of Russia, Scientific and Educational Center "Media Education and Media Competence" of the Taganrog Institute named after A.P. Chekhov, Center for Ecological Education of the Russian Academy of Sciences, Crimean Film and Media Center, Moscow City Pedagogical University and a number of other partner organizations.

It is important to note that CCEE RANEPA has already repeatedly come up to the discussion of the stated problems in cooperation with its partners in recent years. For example, a round table "Media education, media and periodicals in the system of professional education" was successfully held within the framework of the All-Russian Scientific and Practical Conference with International Participation "Secondary Vocational Education: Practice and Management" (December 5-6, 2019) which resulted in inclusion of the following provision in the forum recommendations: "To recommend the Ministry of Culture of Russia, FSO of Russia, Public Movement "Information for All" to continue pushing the practice of creating centers, ensuring access to legal and other socially significant information and centers of media education on the basis of libraries in organizations of secondary vocational education (hereinafter referred to as SVE), focusing stated activities on implementation of paragraph 2 of the Passport of the National Project "Education" in terms of achieving the goal of "education of a harmoniously developed and socially responsible personality considering spiritual and moral values of the peoples of the Russian Federation and their historical and national-cultural traditions. The final document of the conference also included a provision on the need to introduce elements of non-formal and informal education, distance education and media education in SVE; defining the position and role of secondary vocational education in comprehensive development of a human being both in terms of the educational component and health component.

The DVD "Secondary Vocational Education: Practice and Management" issued for the conference also contained information on the subject of media education https://epublish.ru/ranepa/2019/index.htm. Much more information on topics of animation and film education was provided on the CD "Preschool education: problems and prospects for development" https://e-publish.ru/ranepa/2018-I/index.htm (Media education for parents: developing family media literacy; using media education in raising children; information and communication technologies in preschool education; teenagers and screen violence: problems of family education; child and advertising; preschoolers and modern animated movies: problems and solutions; game technology in media education for preschoolers; influence of cartoons on development of preschool children). It should be noted that stated sources have become media educational resources intended for development of the system for training of personnel in organizations of SVE - teacher training colleges and their placement on servers of E-Publish JSC became one of the first steps in forming the profile community serving for purposes of development of a public-private partnership in the field of profile-types SVE and preschool education in conditions of digital transformation.

The second thematic round table "Media Education in the System of Vocational Education" was held together with the conference "Teacher Training College: New Algorithms of Secondary and Additional Vocational Education" in 2020 within the framework of the International Scientific and Practical Conference "Secondary Vocational Education: Practice and Management - 2020" (Saint-Petersburg, December $15-16,2020$ ) which also paid great attention to issues of film education and media pedagogics in Russia.

Within the framework of the IV All-Russian Scientific and Practical Conference "Information Security and Children" (Moscow. RANEPA, IUO RAO, February 27-28, 2020), organized with participation of leading experts of RANEPA, RAS, RAE, RANS, Moscow City Pedagogical University and Academy of Innovative Education and Development, the discussions were held on research on the impact of digital educational environment on the educational process, as well as development of information security and media education components in preschool, general and additional education of children, youth and scientific and pedagogical community. CCEE RANEPA and partners organized and successfully held the round table "Film Education and Media 
Pedagogics in Solving Problems of Information Security for Children" and the session "Animation Activities in Your Smartphone" in March 2021, as part of the V All-Russian Scientific and Practical Conference "Information Security and Children".

Considering, the best regional practices we should also mention experience of the Republic of Crimea, which has now become the leading region of the Russian Federation, where works on development of film education and media pedagogics at the intersection of cultural, educational and communication competencies have been carried out most systematically and effectively. The leader of the process in the region is the Crimean Film and Media Center with its Yalta Film Studio. The Crimean Film Media Center has organized a permanent virtual workshop/media school "Practical Film and Media Education" for school and preschool media teachers and workers in the field of culture (e.g., the online workshop "Practical Film and Media Education Development of Critical Thinking and Skills Required for Analysis of Films and Animation Intended for Preschoolers and Elementary School children" will take place on April 15, 2021, being aimed both at representatives of the preschool education sector itself and at all participants of the educational process in teacher training colleges which train personnel for the needs of the preschool education system - SVE sector).

About 400 teachers of the region have already been trained at the seminars of the Crimean Film and Media Center and courses held at the Crimean Republican Institute of Postgraduate Pedagogical Education, receiving the qualification of a media pedagogue. Film education has already been used for holding of integrated lessons and educational activities in many schools and kindergartens of Crimea as well as within extracurricular activities, including opening of film and animation groups and studios, organizing information and methodological support of these activities. Various creative workshops, special film groups in children's health camps, organized on a shift basis, creative meetings and master classes implemented by leading Russian filmmakers under the auspices of the Russian Union of Cinematographers are also being held currently for children, teenagers and young people in Crimea. The region has seriously raised the question of opening of a film education and media pedagogics department in the system of secondary vocational education.

Currently, it has been decided to return to the issue of film education as a part of the national project "Education", one of the main indicators of which is related to enrollment of children and adolescents in the age range between 5 and 18 in additional general education and preliminary professional programs in the field of arts. In this regard, it shall be noted that formation of media literacy taking place beginning from primary school age will expand the basic stock of knowledge about reality, helping to understand the depth of significance and will also provide an opportunity to apply this knowledge in high school for the goal of further development.

In these conditions, cinema becomes a factor in formation of a personality, it also contributes to personal development and a properly selected film can form a proper dimensional and humanistic view of the world in the hands of a good teacher. Visual experience capabilities begin to be formed in children at the age of about 1.5-2 years, it is the time when a child begins to perceive screen images - firstly - cartoons, subsequently - television and movies. In the course of formation of interests and outlook peculiarities of a child or a young person the primary role is played by the family, but more often parents perceive cinema just as entertainment and some means to occupy their child in a certain way. As an alternative, it is proposed to begin introduction of the potential of animation and cinematography in the educational process beginning from elementary school or even senior preschool age in order to develop the artistic and aesthetic taste of children.

Relevance of the problem under study is conditioned by the fact that there is no basic film education at the level of general education, despite the fact that the interest in cinema and animation is formed at the preschool age. The experience shows that countries which have introduced film education lessons in their school curricula treat films as an art form. An example of this is the concept of multiliteracy in Finland and the free resource for students and teachers of schools in the UK Film Education, where media education is an important component of the national curriculum.

Cinema provided in the form of a documentary film as a supplement to lessons does not form film literacy in children and issues of interaction between schools and mass media are mostly considered from the perspective of educating schoolchildren and college students, usually bypassing the issue of teachers' attitudes and professional readiness to implement film education as an integral part of media education. 
The main concluding point for development of film education in schools was related to approval of the List of Instructions from the President of the Russian Federation which took place as a result of a meeting of the Council for Culture and the Arts, dated October 27, 2020. (p. 5, No. Pr-77, dated January 23, 2021) which provided the orders for the Ministry of Education and the Ministry of Culture to consider the issue of studying the legacy of Russian cinematography as a component of basic general education programs and to submit a report on this issue to the President of the Russian Federation by June 1, 2021.

Proceeding from the aforesaid, the main purpose of the article was to investigate the attitude of future teachers towards integration of cinema education into the elementary school educational process.

\section{Materials and methods}

Setting the research task actualized a special sociological study which included a group of respondents, representing young people at the age of 18-22, receiving secondary vocational teacher training within the specialty 44.02.02 "Teaching in the elementary school. The sample of the concluded study included 318 people.

The sociological research was conducted in several stages. The applied methodology was based on the quantitative method of sociological surveying. The study was conducted in several stages. The preparatory stage included analysis of works of Russian and foreign authors on issues of integrating film education into the school educational process, the goal and objectives of the study were also formulated and special survey tools (questionnaires) were replicated. The field research phase included a survey of respondents on the topic under study. In the course of the data control stage all questionnaires were checked for completeness and correctness by means of visual inspection. In the course of the processing stage, all data obtained during the study was entered into the SSRS databases for further analysis. Processing of primary sociological information was carried out in the course of the final stage of the study, all obtained data was analyzed, reasonable generalizations, conclusions and recommendations for educational authorities and heads of educational organizations of general education were made.

\section{Discussion}

A new version of the law "On Education in the Russian Federation" came into force in terms of students education in September 2020. The social order provided in relation to education dictates the need to educate a harmoniously developed and socially responsible personality on the basis of spiritual and moral values of the peoples of the Russian Federation, historical and national cultural traditions. All these facts determine the need to teach critical perception of information, to develop the ability of independent thinking, analysis, and decision-making. There is no denying that mass media play rather a huge role in upbringing and social adaptation of children. Mass media shape attitudes towards the world to a certain extent, influencing life ideals and spiritual values and determining the perception of other people. It is difficult to overestimate the role of cinema in matters of education and development (Maksimova, 2005). However, the current state of film industry, both Russian and foreign, is more focused on the entertainment aspect (infotainment - information received through entertainment) and educational and upbringing purposes are in little demand and go into the background. Children and young people are watching fewer and fewer domestic films, they are becoming passive consumers at whom certain values are imposed (Brajant, Tompson, 2004). Schools are less and less focused on the prospects of functioning in the field of film pedagogics, although in fact, they play an important role in the process of educating citizens (European..., 2008).

Analysis of various sources has allowed a number of authors (Grashchenkova, 2014; Ivanova, 2012) to justify the widespread use of educational cinematography in the 19th and 2oth centuries. The works point out that certain measures were taken to scientifically justify introduction of cinema in schools already in the 1920s, including methodological issues of using films in the educational process and difficulties of schoolchildren's perception of films. A number of other Soviet scientists considered film education as a part of the system of pedagogical influence on children (Baranov, 2002; Levshina 1983; Razumnyj, 1969). A number of authors reveal the tasks of film education, which have been formulated as an introduction to film aesthetics, development of figurative thinking, formation of artistic experience (Gorbulina, 1984: 196-223; Nechaj, 1989; Penzin, 1987; Usov, 1989). Solution of these tasks contributes to socialization of schoolchildren, 
which allows them to form their own world of cultural, moral and ethical values, to understand their life positions and form attitude towards the surrounding world.

First of all, it is actual for elementary school children, representing children of primary school age, to be characterized by heightened emotionality actual when acquiring knowledge. This fact necessitates selection of visual teaching materials which involve an emotional impact on the child, also touching the sphere of his or her senses (Camarero et al., 2019; Galchenkov et al., 2018; Gudilina, 2014: 8-10). Introduction of the notion of media literacy exactly in the elementary school structure has been confirmed by the data of psychologists, confirming that in case of the primary grades the child's intellect is formed by $80 \%-90 \%$; necessary fundamental skills and abilities are acquired in the same period. The relationship between perception of elementary school children and emotional component is noted in works of many authors (Chelysheva, 2005; Fedorov, 2006: 25-30; Odincova, 1997; Ryzhih, 1997; Sharikov, 2006; Sitnikova, 2001). When watching a film children provide not only empathy to the characters, but also show stereotypes of behavior and opportunities to choose ways of solving certain life situations. Children develop certain moral standards of behavior by analyzing moral conflicts contained in films, which allows them to create certain patterns of behavior; vividness and imagery of actions occurring on the screen can only enhance this effect (Bazhenova, 2004; Chelysheva, 2006; Tihomirova, 1999). Thus, watching movies in primary school can be also determined as turning into a purposeful controlled educational process.

Studies of foreign scientists devoted to modern principles of film and media education at school suggest various options of upbringing and education implemented by means of screen art, analysis of visual coding by students themselves, formation of film art perception, upbringing of literate viewers (Fedorov, 2012; Fedorov, Levitskaya, 2021; Levitskaya, Fedorov, 2021; Masterman, 1985; 1997). Finnish researcher S. Minkkinen developed a media education program, in which the author identified cognitive, ethical, philosophical and aesthetic goals as the main ones in conditions of media education (Minkkinen, 1978).

The main task of the teacher in this case is related to creation of favorable conditions for assimilation of socially significant qualities - moral norms and traditions of the society in which we live. Schooling can be called a process of perception and assimilation of the information offered to children (in general terms). Perception determined as a cognitive process of reality is somewhat different for children than for adults. Peculiarities of perception of younger schoolchildren are characterized by the following features:

- unified perception of the surrounding world;

- high sensitivity;

- emotions prevail over reasoning;

- impulsive acting at the dictate of feelings;

- main criteria for evaluation of a person - good and evil;

- acting by imitation;

- moral ideals - parents, teacher.

Possessing the great visual experience, a child is not always able to comprehend it adequately. A teacher can provide some help in this matter, but there is some contradiction between the need to introduce the basics of film pedagogics into the educational process due to implementation of the FSES BGE and overall non-preparedness of primary school teachers for corresponding procedures. The issue of insufficient development of methodological support remains open for this process. Most works on this topic are devoted to cinema education of schoolchildren, leaving aside issues of professional training of teachers (Baranov, 2002; Danilchuk, 2002; Luman, 2005; Odincova, 1997; Penzin, 2001; Stolbnikova, 2006), however, without any knowledge of the individual attention span of elementary school students, the overall effectiveness of media education integration into the curriculum becomes rather low. A great contribution to development of media education was made by the scientific study "Problems and Prospects for Development of Media Education at Universities in Conditions of Modern Russia", revealing the issues of media literacy, media pedagogics in pedagogical universities (Fedorov, 2005; Demidov, 2016), which can be further adapted to teaching the basics of media literacy in educational organizations of secondary vocational education. The monograph published by this author in 2021 presents an overview of one hundred Soviet films and TV series distributed according to viewers and film critics (Fedorov, 2021). 
Thus, despite the fact that media education is not a required subject in any of the educational standards, including the standard of elementary general education, its influence on formation of elementary school students is great and requires certain participation of a teacher. Whether future teachers are ready for this and how they feel about learning the basics of media literacy in elementary schools represent the focus of this study.

\section{Results}

Solving the tasks of the study provided the following results.

The study confirmed a positive attitude of students in secondary vocational education programs towards implementation of film education in elementary schools. This was reported by $62.0 \%$ of the respondents, who believed that film education should be integrated into the curriculum, 24.0 \% suggested the use of movies as an additional source of information in a classroom for ensuring greater visibility (Figure 1). Considering those who were not prepared to teach the basics of film education (14\%), almost all participants cited a low level of teacher awareness in terms of the main goals, objectives and content of media education as an argument. A small number of those surveyed $(7.8 \%)$ expressed doubts about the necessary technical equipment for schools and $31.4 \%$ said they were not familiar with requirements provided for film classes organization for younger students.

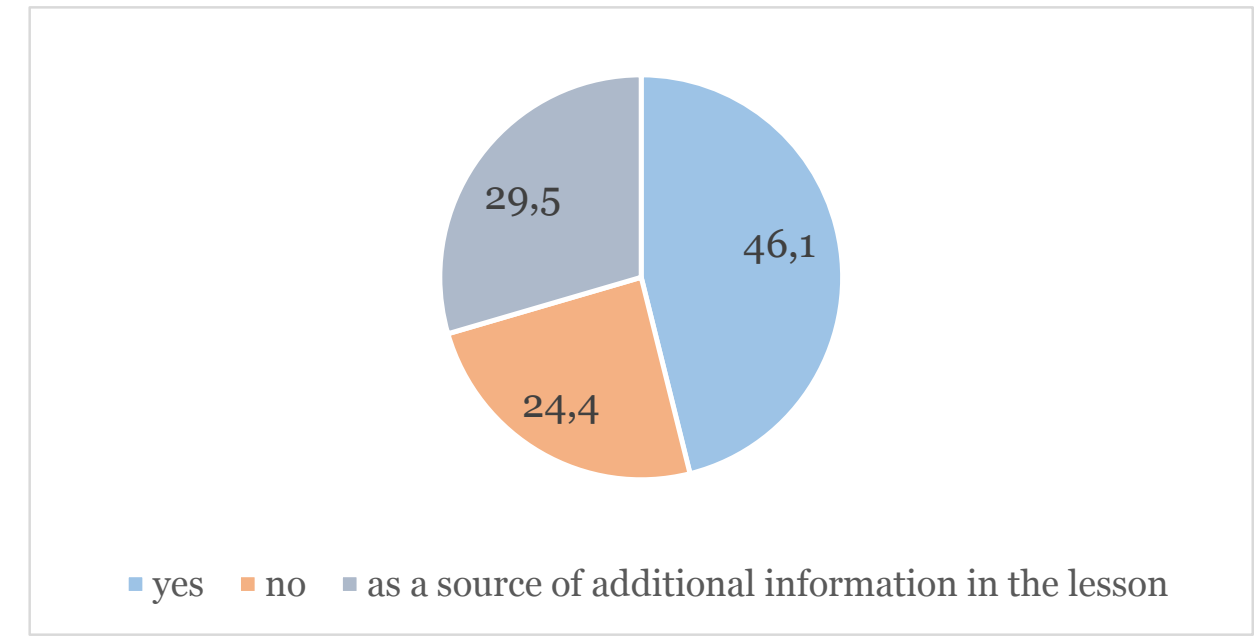

Fig. 1. Do you think that it is necessary to introduce cinema education in schools?

According to respondents, the main objectives of film education are related to teaching children to work with various media sources (18.3\%) and to develop moral skills (12.1\%), while $56.7 \%$ of respondents mentioned development of critical thinking as the main objective of film education.

Respondents' answers regarding the forms of work with children in basic cinematography classes can be roughly divided into three types. The first includes oral activities such as discussions with the teacher carried out before and/or after viewing a film, reading excerpts from the book the film is based on and discussing the film with classmates. The second type of work with students is represented by written work which includes writing tasks, reviews and essays. The third form of work with children can be called "game" since it is based on organization of film quizzes and movie nights (open-air cinemas have been very popular in schools in the warm season recently), exhibition of drawings, creation of collages (Figure 2). The possibility of individual work with students was not excluded from the list according to $2.3 \%$ of the respondents.

As it can be seen from Figure 2, the majority of the respondents preferred verbal forms of work with students. Respondents named formation of communicative competence, widening of the horizons in the field of cinema art, selection and critical analysis of information as basic educational goals of the film education process. Educational goals were formulated as formation of the emotional perception culture, reflection and self-analysis skills, implementation of artistic and creative potential of children, promotion of individuality formation principles. The results of the respondents' readiness to work in proposed conditions are shown in Figure 3. 


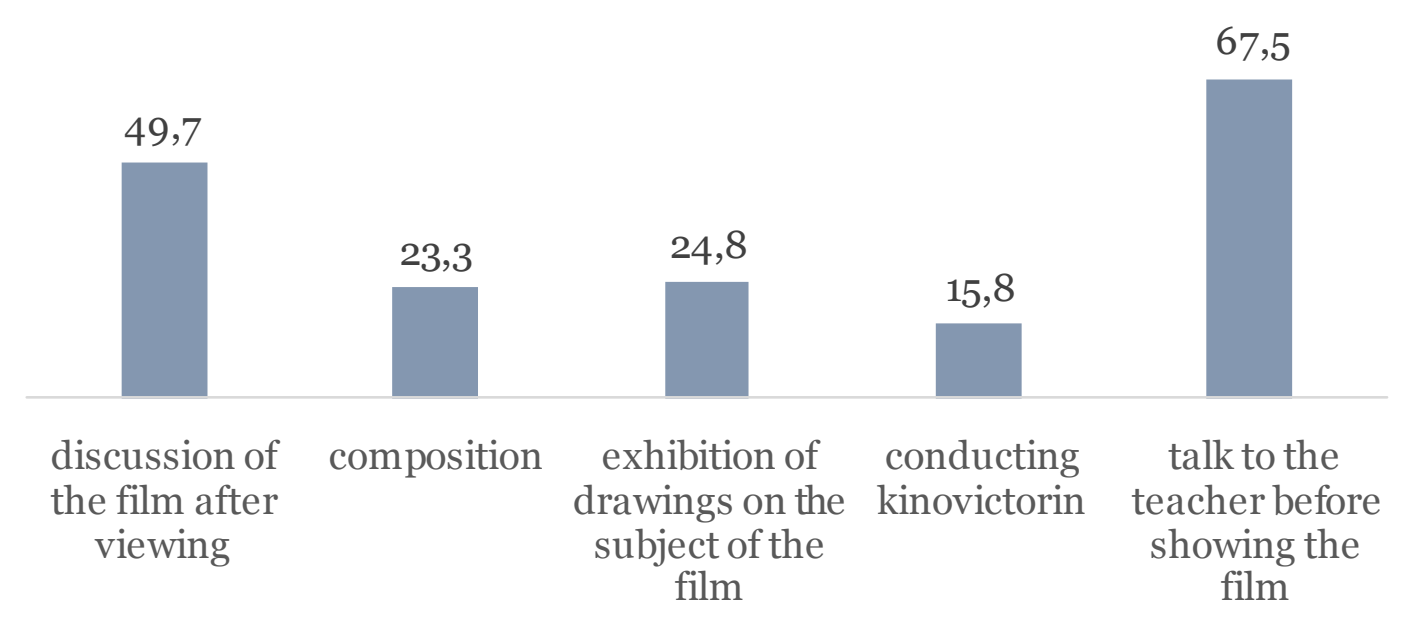

Fig. 2. Forms of work with younger school-age children implemented in basic cinematography classes, \%

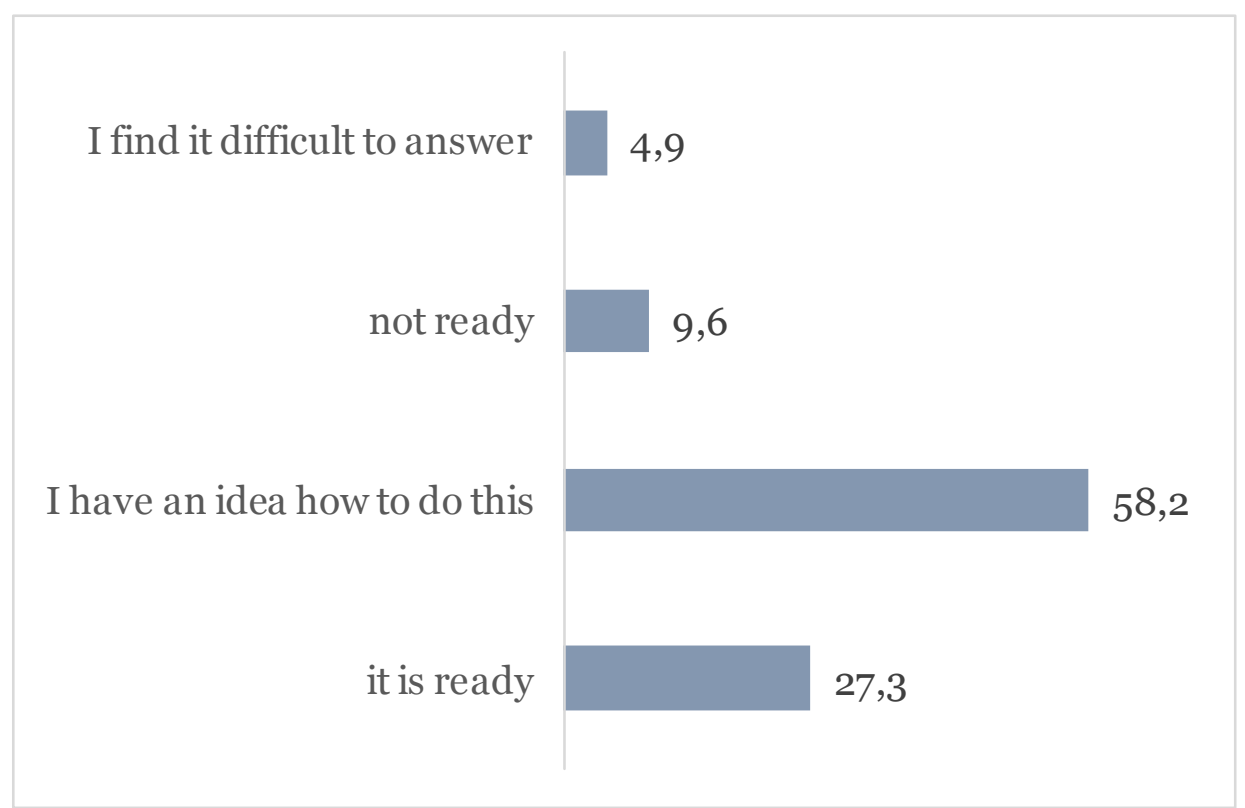

Fig. 3. Readiness of future elementary school teachers to implement film education in school conditions, \%

Summarizing the aforementioned facts, we can say that spectacular arts, namely, animation, film and television occupy a leading position in the life of students currently but they are mostly absent or reduced to the circle movement in the structure of art education. Most of the future elementary school teachers have no knowledge of the subject while understanding the necessity of integrating film education and media pedagogics into the school process.

\section{Conclusion}

Nowadays the screen arts acquire special importance in solving the tasks of upbringing and education. The teacher's job is to show children how to perceive and identify the main idea of a film properly as well as to implement purposeful education of adolescents' aesthetic taste and moral preferences, involving formation of a sustainable interest in the artistic forms of art. In this case, we should also talk about orientation of teachers implemented not to ensure that the child's personality corresponds to a unified level of upbringing, rather to create conditions for a positive dynamic of personal development.

The sociological survey showed that the majority of future teachers are not ready to introduce film pedagogics in the educational process of elementary school, although they are aware of this 
need. Thus, future teachers show an urgent need to use methods of film education in their activities but at the same time they suffer from the lack of necessary knowledge required to implement it in practice.

In conclusion, we would like to note that each non-prepared viewer provides certain lowering of the set limit, when he or she is not engaged in self-development implemented in order to comprehend a film and of course there should be a certain "fitting" of films to unambitious tastes of various people.

At the same time there is certain understanding that processes of film education, gamification and edutainment (informing through education) involving animation and film media, avatar-building, computer graphics, artificial intelligence, robotics and other digital technologies are now becoming the most effective tool that makes the educational process for children and teenagers more relevant, engaging, interesting, easy and understandable, while not destroying the overall canvas of the traditionally strong classical system of Russian education. It seems that stated technologies can also be effective in solving the problems of civic, patriotic, informational-legal, spiritual-moral education and upbringing in the broad sense. At the same time, they are considered both as a format for development of television and Internet content and as means for social design, including those implemented within the framework of commonly applied volunteer activities, including counteracting the ideology of violence, propaganda of addictions, terrorism and considering application in the educational sphere and youth environment.

\section{Acknowledgments}

This article has been provided within the framework of the RANEPA State Assignment No. 11.5 "Research of models analyzing transformation of secondary vocational education regional systems and their resource needs" for 2021. The research was determined by a number of partnermade works in the field of film education, media pedagogics and information security of children and youth in Russia.

\section{References}

Baranov, 2002 - Baranov, O. (2002). Mediaobrazovanie v shkole i v vuze [Media education in school and university]. Tver. [in Russian]

Bazhenova, 2004 - Bazhenova, L. (2004). Mediaobrazovanie shkol'nika (1-4 klassy) [Media education of a schoolboy (grades 1-4)]. Moscow. [in Russian]

Brajant, Tompson, 2004 - Brajant, J., Tompson, S. (2004). Osnovy vozdejstviya SMI [Fundamentals of Media Impact]. Moscow. [in Russian]

Camarero et al., 2019 - Camarero, E., Fedorov, A., Levitskaya, A. (2019). Audiovisual and media literacy for social change. The Routledge Handbook of Positive Communication: Contributions of an Emerging Community of Research on Communication for Happiness and Social Change: 356-363.

Chelysheva, 2005 - Chelysheva, I. (2005). Mediaobrazovanie v nachal'noj shkole [Media education in primary school]. Media Education. 2: 107-108. [in Russian]

Danil'chuk, 2002 - Danil'chuk, E. (2002). Teoretiko-metodologicheskie osnovy formirovaniya informacionnoj kul'tury budushchego pedagoga [Theoretical and methodological foundations of the formation of information culture of the future teacher]. Rostov. [in Russian]

Demidov, 2016 - Demidov, A. (2016). Centry etiko-pravovoj informacii i mediaobrazovaniya na baze shkol'noj biblioteki - novaciya $\mathrm{v}$ realizacii FGOS i infrastruktura dlya razvitiya informacionno-pravovoj kul'tury detej i molodyozhi [Centers of ethical and legal information and media education on the basis of the school library-innovation in the implementation of the Federal State Educational Standard and infrastructure for the development of information and legal culture of children and youth]. Media Education. 2: 21-33. [in Russian]

European..., 2008 - European Parliament Resolution on Media Literacy in a Digital World.

Fedorov, 2005 - Fedorov, A. (2005). Mediaobrazovanie budushchih pedagogov [Media education of future teachers]. Taganrog. [in Russian]

Fedorov, 2006 - Fedorov, A. (2006). Mediaobrazovanie dolzhno stat' chast'yu uchebnyh programm [Media education should become a part of educational programs]. Peremena. 3: 25-30. [in Russian] 
Fedorov, 2012 - Fedorov, A. (2012). Analysis of art house media texts use during media studies in the student audience (Alain Robbe-Grillet movies case study). European Journal of Contemporary Education. 2(2): 112-123. DOI: 10.13187/ejced.2012.2.112

Fedorov, 2021 - Fedorov, A. (2021). 100 samyh populyarnyh sovetskih telefil'mov i serialov: mneniya kinokritikov i zritelej [100 most popular Soviet TV films and series: opinions of film critics and viewers]. Moscow. [in Russian]

Fedorov, Levitskaya, 2021 - Fedorov, A., Levitskaya, A. (2021). Media manipulation and movies. Media Education. 17(1): 64-69. DOI: 10.13187/me.2021.1.64

Fedorov, Levitskaya, 2021 - Fedorov, A., Levitskaya, A. (2021). Theoretical model and technology of anti-Russian propaganda in internet communications of modern Ukraine within the framework of various student groups' media literacy education. Media Education. 17(3): 443-452. DOI: $10.13187 / \mathrm{me} .2021 .3 .443$

Galchenkov et al, 2018 - Galchenkov, A., Demidov, A., Komarova, I., Tret'yakova, A. (2018). Integraciya mediaobrazovaniya, pravovogo prosveshcheniya i pravovoj informatizacii v usloviyah sovremennoj shkoly [Integration of media education, legal education and legal informatization in the conditions of modern school]. Moscow [in Russian]

Gorbulina, 1984 - Gorbulina, E. (1984). Osnovy kinoiskusstva. Programmy pedagogicheskih institutov [Fundamentals of cinema art. Programs of pedagogical institutes]. Moscow. [in Russian]

Grashchenkova, 2014 - Grashchenkova, I. (2014). Kinoantropologiya XX/20 [Film anthology XX/20/]. Moscow. [in Russian]

Gudilina, 2006 - Gudilina, S. (2006). Modernizaciya obshchego srednego obrazovaniya: mediaobrazovanie $\mathrm{i}$ informacionno-kommunikativnye tekhnologii [Modernization of general secondary education: media education and information and communication technologies]. Moscow. [in Russian]

Ivanova, 2012 - Ivanova, L. (2012). Liniya kinoobrazovaniya v pedagogike Rossii (konec XIX - XX vv.) [The line of film education in pedagogy of Russia (late XIX - XX centuries)]. Magister Dixit. 2: 73-93 [in Russian]

Levitskaya, Fedorov, 2021 - Levitskaya, A., Fedorov, A. (2021). Theoretical model of media competence's development of teachers-to-be in the process of the analysis of manipulative media influences. Media Education. 17(2): 323-332. DOI: 10.13187/me.2021.1.323

Levshina, 1983 - Levshina, I. (1983). Kak vosprinimaetsya proizvedenie iskusstva [How a work of art is perceived]. Moscow. [in Russian]

Luman, 2005 - Luman, N. (2005). Media kommunikacii [Media communications]. Moscow. [in Russian]

Maksimova, 2005 - Maksimova, G. (2005). Mediapedagogika kak odno iz napravlenij sovremennogo obrazovaniya [Media pedagogy as one of the directions of modern education]. Izvestiya vuzov. Severo-Kavkazskij region. 4: 119-123. [in Russian]

Masterman, 1985 - Masterman, L. (1985). Teaching the Media. London: Comedia.

Masterman, 1997 - Masterman, L. (1997). A Rational for Media Education. In: Kubey, R. (Ed.) Media Literacy in the Information Age. New Brunswick (U.S.A.) and London (UK).

Minkkinen, 1978 - Minkkinen, S. (1978). A General curricular model for mass media education. Paris: UNESCO.

Nechaj, 1989 - Nechaj, O. (1989). Osnovy kinoiskusstva [Fundamentals of cinema art]. Moscow. [in Russian]

Odincova, 1997 - Odincova, S. (1997). Dialog literatury i kinoiskusstva v uchebnom processe. Problemy kinoobrazovaniya v vuze i v shkole [Dialog of literature and cinema art in the educational process. Problems of film education in higher education and in school]. Kurgan. [in Russian]

Penzin, 2001 - Penzin, S. (2001). Osnovy kinoiskusstva [Fundamentals of cinema art]. Voronezh. [in Russian]

Razumnyj, 1969 - Razumnyj, V. (1969), Esteticheskoe vospitanie. Sushchnost'. Formy. Metody [Esthetic education. The entity. Forms. Methods]. Moscow. [in Russian]

Ryzhih, 1997 - Ryzhih, N. (1997). Hudozhestvennoe vospitanie uchashchihsya obshcheobrazovatel'nyh uchrezhdenij na materiale ekrannyh iskusstv [Artistic education of students of general education institutions on the material of screen arts]. Taganrog. [in Russian]

Sharikov, 2006 - Sharikov, A. (2006). Shag navstrechu: kino, nauka, obrazovanie [Step towards: cinema, science, education]. Media Education. 1: 10. [in Russian] 
Sitnikova, 2001 - Sitnikova, N. (2001). Didakticheskie problemy ispol'zovaniya audiovizual'nyh tekhnologij obucheniya [Didactic problems of the use of audiovisual learning technologies]. Moscow. [in Russian]

Stolbnikova, 2006 - Stolbnikova, E. (2006). Razvitie kriticheskogo myshleniya studentov pedagogicheskogo vuza $\mathrm{v}$ processe mediaobrazovaniya [Development of critical thinking of pedagogical university students in the process of media education]. Taganrog. [in Russian]

Tihomirova, 1999 - Tihomirova, K. (1999). Issledovanie urovnya mediaobrazovatel'noj podgotovki mladshih shkol'nikov [Research of the level of media education training of primary school students]. Shkola 20oo. Moscow. [in Russian]

Usov, 1994 - Usov, Yu. (1994). Osnovy ekrannoj kul'tury (I-XI klassy) [Fundamentals of screen culture (I-XI classes)]. Moscow. [in Russian] 